\title{
PRE-EMPTION, BACK-IN AND REDEMPTION RIGHTS AS WELL AS THE RIGHT OF PRIORITY IN ACQUISITION OF REAL ESTATE
}

\author{
Katarzyna A. Dadańska, PhD \\ Faculty of Law and Administration \\ The University of Szczecin \\ e-mail:dadanska@mec.univ.szczecin.pl
}

\begin{abstract}
Among factors that might significantly diversify common and economic trading, in particular trading in real estate, pre-emption, back-in and redemption rights, as well as the right of priority in acquisition play an important role. These legal instruments, despite certain differences in their legal structures, serve a similar function. Namely, they may be utilized for the purpose of affecting the preferred ownership structure. The legislator in pursuit of the assumed ownership structure may - through the instruments of the pre-emption right, back-in right, redemption right and the right of priority in acquisition - particularly with their statutory character - restrict freedom to trade in ownership with regard to the selection of the real estate purchaser. Simultaneously, in the contracting process, the parties face a certain manner of proceeding imposed, the purpose of which is to conclude the contract on transferring real estate ownership with the partner preferred by the legislator. In certain cases, the legislator goes even further, granting the eligible party a claim under which the eligible party may demand that the party obliged shall submit an appropriate declaration of will, and in the event that the party obliged refuses - the eligible party may seek the judgment of the court replacing that declaration. Proper navigation in the field of real estate trading, in particular with regard to transactions in which the pre-emption right, back-in right, and redemption right, or the right of priority in acquisition is reserved for defined entities, requires defining the legal character of the given instrument, the manner of executing the due right by the eligible party, results of the failure of the parties to the contracting process to fulfill the obligations imposed by the act, and finally, defining whether there are means for the compulsory execution of the power guaranteed by the act and, if yes, what these means are.
\end{abstract}

Key words: property law, contract law, real estate markets.

JEL Classification: K11, K12, R30.

Citation: Dadańska K.A., 2015, Pre-emption, Back-in and Redemption Rights as Well as the Right of Priority in Acquisition of Real Estate, Real Estate Management and Valuation, Vol. 23, No. 1, pp. 63-74.

DOI:10.1515/remav-2015-0006

\section{Introduction}

Among factors that might significantly diversify common and economic trading, in particular trading in real estate, pre-emption, back-in, redemption rights, as well as the right of priority in acquisition, play an important role. These legal instruments, despite certain differences in their legal structures, serve a similar function. Namely, they may be utilized for the purpose of affecting the preferred ownership structure. The legislator in pursuit of the assumed ownership structure may - through the instrument of pre-emption right, back-in right, redemption right and the right of priority in acquisition - particularly with their statutory character - restrict freedom to trade in ownership with regard to the selection of the real estate purchaser (TRUSZKIEWICZ 1998, p. 196). Simultaneously, a certain manner of proceeding is imposed on the parties in the contracting process, the purpose of 
which is to conclude the contract on transferring real estate ownership with the partner preferred by the legislator. In certain cases, the legislator goes even further, granting the eligible party a claim under which the eligible party may demand that the party obliged shall submit an appropriate declaration of will, and in the event that the obliged party refuses - the eligible party may seek the judgment of the court replacing that declaration (SUPREME COURT 1967, III CZP 32/66; SUPREME COURT 2002, II CKN 1035/00). Obviously, the pursuit to the preferred ownership structure may stem from various reasons. It may constitute "an element of the state economic policy"(ŻUŁAWSKA et al. 1999, p.107; SWACZYNA 2000, p. 74), or it may be considered as an auxiliary instrument for the acquisition and recovery of municipal, agricultural or forest land for the purpose of their rational management, or finally, an instrument of managing land (TRUSZKIEWICZ 1998, p. 196), of defined purpose, constituting the property of the State Treasury, units of territorial self-governments or other entities, including private ones. Finally, it may constitute a means of protecting owners against ownership loss (BAKER, MiCELI, SIRMANS 2008, pp. 31-45). The Constitutional Court, with reference to priority in acquisition (provided for in Art. 23 item 4 of the no longer binding Act of 29 April 1985 on land management and real estate expropriation, Journal of Laws No. 22, item 99 as amended), pointed out that this instrument expresses legislative re-privatization tendencies, which are also justified by the constitutional principles of social justice and respecting ownership, constituting one of the crucial principles of the real estate disposing system defined in the Act, with regard to public real estate, and demonstrating, above all, moral dimension (CONSTITUTIONAL COURT 1996 , W 19/95).

Changes in the system which occurred in Poland at the turning of the eighties and nineties of the XX century, in spite of the fact that they led to the considerable limitation of the discussed instruments, particularly in the form of the statutory pre-emption right, back-in right, and redemption right, did not, however, eliminate them completely from Polish law (TRUSZKIEWICZ 1998, p. 198). It is significant that, despite the limitations regarding those instruments, their application still causes problems. The sudden increase in real estate trading occurring since 1990 has caused the existence of the pre-emption right, back-in right, and redemption right, as well as the right of priority in acquisition, to become even more troublesome. Together with the increasing interest in real estate, there appear more and more clashes of interests between purchasers of real estate or usufruct covered by the statutory pre-emption right, back-in right, or redemption right, and parties eligible under these statutory rights, interested in and pursuing the purchase of real estate or the usufruct right through the execution of the right due to them (TRUSZKIEWICZ 1998, p. 199). One may also notice the clash between the interests of entities owning given real estate (among others, company apartments) who are interested in maintaining a certain number of such apartments at their disposition due to the necessity of conducting defined tasks, and the interests of persons interested in purchasing them (very often on very preferential terms (CONSTITUTIONAL COURT 2003, K 24/01).

Real estate market transparency, in particular through a friendly legal environment, stabilizes the playing field for investors in real estate (PIET, EICHHOLZ, GUGLER, KOK 2011, pp. 152-173). The purpose of this study refers to conducting, with regard to the Polish law, a legal and comparative analysis of four institutions: the preemption right, back-in right, redemption right, and the right of priority in acquisition of real estate. The above-mentioned analysis will allow to present the similarities and differences in the discussed institutions, and the assessment of the current legal status and formation of de lege ferenda conclusions, important from the perspective of works being conducted on the new Civil Code. In light of works carried out by the Civil Law Codification Commission, the question regarding the future shape of the selected institutions is essential; that is, whether the legislator should, as has been the case, differentiate these institutions, as well as the place of their regulation (the Civil Code, detailed acts), or rather work towards restricting (or unifying) them, with a transparent insertion of the basic framework of regulations referring to the given institution in the Civil Code (at this point a subsequent question arises with regard to where in the Civil Code such an insertion should be made), with their simultaneous special (lex specialis) and exceptional normalization in specific laws.

Four research methods have been implemented in the work: the formal-dogmatic, legalcomparative, historical-legal methods, as well as the empirical method. With regard to the formaldogmatic method, the thesis presents a depiction of the main legal regulations that are related to the analyzed institutions. The legal-comparative method was applied to the comparison of the said institutions from the perspective of four factors selected by the author: the legal character of the given instrument, the manner of executing the right vested with the authorized entity, results of the failure 
of the parties to the contracting process to fulfill the obligations imposed by the act, and finally, specification of whether there are any means by which the right guaranteed by the act can be enforced and, if so, what such means are. The historical - comparative method has been intended to present the direction of changes the discussed institutions have been undergoing since the system changes of the XX c. The article provides an analysis of the most important decrees of the Supreme Court and the constitutional Tribunal referring to the examined issues.

So far, a collective comparison of the discussed institutions has not been conducted in the doctrine. It is only indicated in a signaling manner that, with regard to the given instrument, it may exert an influence on the shaping of the preferred ownership structure (ŻUŁAWSKA 1999, p. 107; SWACZYNA 2000, p. 7; TRUSZKIEWICZ 1998, p. 196; BAKER, MICELI, SIRMANS 2008, pp. 31-45; TK of 18.06.1996, W 19/95) and moreover, that limitations of ownership rights are omnipresent in the law and may have economic justification (MICELI, SIRMANS 2005, pp. 405-415). It is also justly pointed out that, among numerous determinants of investment in real estate (which include economic growth, urbanization, demographic boom, legal surroundings), those unwanted include the lack of transparency in the regulatory framework, as well as administrative and legal limitations (LIESER, GROH 2014, pp. 611659). The article poses a supplementary hypothesis that the examined institutions constitute factors limiting trading in real estate, which simultaneously secure the interests of the selected entities. Thus, they are of considerable economic significance.

\section{The pre-emption right}

The pre-emption right is intended to secure the priority of acquisition of a defined item to a given person before other potential purchasers (BIENIEK, RUDNICKI 2011, p. 540). This right plays a significant role in economic trading, in particular in cases when the source of the pre-emption right stems from the provisions of an act. Polish legislation provides for numerous cases of the so-called statutory preemption right, with the majority of them referring to real estate. In most cases, the pre-emption right is vested in the State Treasury (see Art. 24 item 5a of the Act of 19th October 1991 on Managing Agricultural Real Estate of the State Treasury, Journal of Laws of 2012 item 1187 as amended; Art. 10 item 5 of the Act of 16 ${ }^{\text {th }}$ April 2004 on Environmental Protection, Journal of Laws of 2013 item 627 as amended; Art. 59 item 1 of the Act of $5^{\text {th }}$ June 1998 on the Regional Self-Government, Journal of Laws of 2013 item 596 as amended; Art. 4 item 2 of the Act of 20 th December 1996 on Sea Ports and Harbors, Journal of Laws of 2010 No. 33, item 179), units of territorial self-governments, but also other entities, e.g. co-owners of agricultural property (see Art. 109-111 of the Act on Real Estate Management; Art. 38 item 5 of the Act of 28 ${ }^{\text {th }}$ September 1991 on Forests, Journal of Laws of 2011, No. 12, item 59 as amended; Art. 26 item 2 of the Act of $29^{\text {th }}$ June 1963 on Joint Land Property Management, Journal of Laws No. 28 item 169 as amended; Art. 166 of the Civil Code, lessees of agricultural property (Art. 695 $\S 2$ of the Civil Code; Art. 3 item 1 of the Act of 11 th April 2003 on the Forming of the Agricultural System, uniform text, Journal of Laws of 2012, item 803), or administrators of a special economic zone (see Art. 8 item 2 of the Act of 20th October 1994, Journal of Laws of 2007 No. 42, item 274 as amended). The violation of powers stemming from the pre-emption right may be subjected to the sanction of invalidity. It may also result in liability in damages. For this reason, aspects related to the pre-emption right to real estate are of crucial importance for real estate trading, constituting, on the one hand, a restriction in the contractual freedom of the parties through the option of demanding the selection of the partner (purchaser) from the seller (TRUSZKIEWICZ 1998, p. 196) defined in the act, as well as imposing a defined manner of concluding the contract transferring the ownership of real estate (in the first sequence, the contract obliging to transfer ownership - the so called contingent real estate sales contract, and only next, after its execution, the contract transferring ownership), and on the other hand - constituting the cause of real estate trading diversification due to the subject of the purchase the character of the real estate (e.g. agricultural property, monument, etc.), the source of its previous purchase, its purpose in the development plan, location and other factors. The pre-emption right, in particular statutory pre-emption, constitutes an instrument which affects the ownership structure, especially in the field of real estate trading. In the previous system, the pre-emption right was used, among others, as "an auxiliary instrument of acquisition and recovery of municipal, agricultural or forest land for the purpose of their rational management" (TRUSZKIEWICZ 1998, p. 196). The range of this instrument, in particular in the form of statutory pre-emption, was obviously wider at that time than currently (DOMIŃCZYK 1996, p. 57). The pre-emption right, in conditions of the principle of a 
homogenous state property fund, often demonstrated a restrictive character. This is illustrated by the Act of $24^{\text {th }}$ January 1968 on the obligatory redemption of the real estate falling into the composition of agricultural holdings (Journal of Laws No. 3, item 14), which provided for the State Treasury's preemption right to purchase agricultural property, if the agricultural holding was assessed as presenting a low level of the agricultural production (DOMIŃCZYK 1996, p.58), and was considered to be one of the forms of "expropriation against the return of real estate value" (CZARNECKI 1963, p. 1193).

The pre-emption right constitutes an instrument known not only to Polish civil law. It is familiar to and applied by contemporary civil law systems of many countries (e.g. Germany, Austria, Switzerland) (GÓRECKI2000, p. 76). Currently, regulations referring to the pre-emption right have been included in the Civil Code (in Art. 596-602, 695 § 2, 166), in the Act of 21 st August 1997 on Real Estate Management (Journal of Laws of 2010 No. 102, item 651 as amended), as well as numerous specific acts. The definition of the pre-emption right is presented in Art. 596 of the Civil Code. The reservation of the pre-emption right effects the occurrence of the power of a defined entity to enjoy the right of priority in the acquisition of an item (real estate) in the event that the party obliged were to conclude a sales contract with a third party (BIENIEK, RUDNICKI 2011, p. 540). The definition of the pre-emption right regulates that it may be executed exclusively in relation to the sale of the item, and not at the initiative of the eligible entity (SUPREME COURT 1974, III CRN 235/74).

The provisions of the Civil Code devoted to pre-emption (Art. 596-602) regulate the contractual and statutory pre-emption rights virtually uniformly. Differences refer to the source of reserving such a right (in the contract or act - Art. 596 of the Civil Code), the results of the outright sale of the item (Art. $599 \S 1$ and 2 of the Civil Code) and additional benefits provided for in the sales contract concluded between the party obliged under the pre-emption right and a third party (Art. $600 \S 2$ Sentence 2 of the Civil Code). The basic construction of the contractual and statutory pre-emption right is, in principle, identical (SWACZYNA 2000, p. 80; KUNICKI 1966, p. 1529).

The construction of the contractual pre-emption right is related to the legal activity establishing the law. Thus, the aspect of the construction of the contractual pre-emption right and its legal nature are very often considered in combination with the legal character of the legal activity establishing that right (GÓRECKI 2000, p. 66).

The legal character of pre-emption has been a subject of interest to the Polish as well as foreign doctrine, and there have appeared numerous concepts related to it (GÓRECKI 2000, p. 66). Among numerous attempts to explain the legal character of pre-emption, the most useful one refers to the concept treating the pre-emption right as a unilateral-modification clause. In fact, this is the only concept allowing the nature of the pre-emption right to be clarified, irrespective of the source of its origin (GÓRECKI 2000, p. 76). It has been reflected by the contemporary doctrine of civil law (GAWLIK et al. 2010, p. 178; GÓRECKI 2000, p. 80; BIENIEK, RUDNICKI 2011, p. 540), as well as in jurisprudence (SuPREME COURT 2002, IV CKN 784/00; SuPREME COURT 2008, II CNP 70/08), although its beginnings date back to much earlier. It is believed to have been established by German lawyers: K. Schuring and K. Larenz (LARENZ 1959, p. 89, p. 159; SCHURING 1975, pp. 306-307; cited after SWACZYNA 2000, p. 80; GÓRECKI 2000, p. 76). In compliance with the concept referred to, the reservation of the pre-emption right does not establish any commitment, even a conditional one, to transfer ownership. It causes the creation of rights vested in the person for whom pre-emption has been reserved with the unilateralmodification clause (GÓRECKI 2000, p. 77; GAWLIK et al. 2010, p. 178; SZPUNAR 1964, p. 373; BIENIEK, RUDNICKI 2011, pp. 540-541), granting priority in the acquisition of ownership in a defined item (real estate) in the event that the owner decides to sell it. The party obliged under the pre-emption right has the obligation to respect this unilateral-modification clause (GAWLIK et al. 2010, pp. 178-179).

The unilateral-modification clause establishes the competence of the eligible party to establish, change or cease an already existing legal relationship through unilateral legal activity. In the case of executing the unilateral-modification clause, the other party has the obligation to recognize the new legal situation and adjust its further proceedings (ZIEMIANIN, KUNIEWICZ 2007, p. 53; PYZIAKSZAFNICKA et al. 2007, pp. 709-712) to such a situation. Thus, the pre-emption right enables, by the submission of a declaration of its execution, the sales contract to be concluded and legal relationship to be formed (SZPUNAR 1964, p. 373; GÓRECKI 2000, p. 181). The execution of the pre-emption right burdens the other party with the obligation to respect the new legal situation and adjust its proceedings to such a situation. The reservation of the pre-emption right does not cause the occurrence of a legal relationship, but it does result in the creation of a specific "bonding state" between the parties. At that time, there are no rights or obligations, the party obliged shall, however, 
expect that, in the case the item is put up for sale, a defined person shall have the pre-emption right (SWACZYNA 2000, p. 81). This "bonding" is similar to the obligation relationship. With regard to this status, it is justified to construe a unilateral-modification clause. The execution of this clause is dependent on the conclusion of a sale contract referring to the item covered by the pre-emption right between the party obliged with a third party to the conditional contract. It is important that this event shall not be considered as the condition referred to in Art. 89 of the Civil Code (GóRECKI 2000, pp. 8182).

The contractual pre-emption right exists already from the moment the legal activity establishing it becomes effective, that is usually the moment it is conducted. The legal activity reserving the preemption right may be conducted in any form, the pre-emption of real estate being no exception. The wording of the provisions allows to clearly distinguish the activity reserving the pre-emption right from the activity constituting the execution of the existing right. The act provides for a requirement to submit the declaration of will in a defined form only with reference to the execution of the preemption right (Art. 597 § 2 Sentence 2 of the Civil Code) (SUPREME COURT 2002, IV CKN 784/02).

The statutory pre-emption right occurs the moment when the provisions of the act which reserve such a right enter into force, with the assumption that such provisions shall regulate the relations established after that moment (SWACZYNA 2000, pp. 74, 87).

In the case the decision to sell real estate is taken with regard to real estate covered by the preemption right, the owner of the real estate may not conclude the contract transferring ownership with the purchaser (with the material consequence). The reservation of the pre-emption right may not be conducted with reference to any contract other than the sales contract (BIENIEK, RUDNICKI 2011, p. 542). The definition of the pre-emption right points out that it may be executed exclusively in relation to the sale of the item, and at the initiative of the party authorized (SUPREME COURT 1974., III CRN 235/74; SUPREME COURT 1996, III CZP 10/96). To the contrary, Gawlik points out that the pre-emption right may be reserved not only with regard to the sales contract and that the source of the pre-emption right may also refer to other contracts, autonomous legal activity constituting an autonomous legal relationship, or an act (GAWLIK et al. 2010, p. 178).

The owner will be obliged to follow the manner of concluding the contract transferring ownership in real estate imposed by the act. That is, the owner shall observe the obligation to divide the sales contract into two stages. Within the scope of the first stage, the conditional sales contract will be concluded as the contract obliging ownership in real estate to be transferred, which, however, does not transfer such ownership to the purchaser. The possibility of including a condition obliging to transfer ownership in real estate in the contract is accepted under the provisions of Art. 157 of the Civil Code. This condition subordinates the possibility of concluding the contract transferring ownership in real estate to whether the entity eligible under the pre-emption right has the intention to exercise such right. It is necessary to inform the party eligible under the pre-emption right about the wording of the conditional contract concluded with a third party, in order to enable the entity to make a decision whether or it is willing to exercise such right. Usually, this is effected by providing the eligible party with an extract of the notary deed referring to the conditional contract (BIENIEK, RUDNICKI 2011, pp. 545-548; SUPREME COURT 1967, III CZP 86/66). If the entity who holds the preemption right, being informed about the wording of the contract concluded between the owner of the real estate and a third party, declares that it [the entity] is not going to exercise the right vested in it, or does not submit the declaration within the period specified in the act, then the parties to the obliging contract may proceed to the next stage - the conclusion of the sales contract transferring ownership, namely the contract with a material consequence. With regard to real estate, Art. $598 \S 2$ of the Civil Code provides for a period of one month to submit such a declaration. Specific provisions may, however, provide for other periods.

Until the moment the entity eligible submits the declaration on the execution of such right, amending the conditional contract or even its termination is acceptable. It is also possible to insert a reservation of the right to withdraw into the conditional contract. Of course, the entity with the priority of acquisition shall be once again notified of the amendment made to the conditional contract (BIENIEK, RUDNICKI 2011, p. 547; SUPREME COURT 2004, ICK 191/04).

The second stage (namely the conclusion of the contract transferring ownership) will not be effected between parties to the conditional sales contract if the entity for whom the contractual or statutory pre-emption right has been reserved has the intention to exercise its powers. In compliance 
with Art. $597 \S 2$ of the Civil Code "the pre-emption right is exercised by a declaration submitted to the party obliged. In the event that the conclusion of the contract on the sale of the item which is subjected to the pre-emption right requires the observation of a special form, then the declaration on the execution of the pre-emption right shall be submitted in the same form". With regard to real estate (perpetual usufruct), the form of a notary deed (see Art. 158 of the Civil Code and Art. 237 of the Civil Code) will be required for the execution of the pre-emption right (DOMIŃCZYK 1996, p. 68).

Pursuant to Art. $600 \S 1$ of the Civil Code, a consequence of the execution of the pre-emption right is that a sales contract of the same wording as the contract concluded between the party obliged and a third party is concluded between the party obliged and the party eligible. Such a contract evokes material consequences (BIENIEK, RUDNICKI 2011, p. 548), that is the sale contract between the seller and the eligible entity who executed its pre-emption right on conditions specified in the sales contract is concluded (SUPREME COURT 2008, II CNP 70/08). The act regulates expressis verbis that the effect in the form of transferring ownership occurs between the parties without the necessity of conducting any further activities (GAWLIK et al. 2010, p. 185; SUPREME COURT 2008, II CNP 70/08). On the other hand, the effectiveness of the execution of the pre-emption right does not depend on the payment of the sales price or its submission to the court deposit (SUPREME COURT 2009, V CSK 43/09; WATRAKIEWICZ2010, p. 55; BIENIEK, RUDNICKI 2011, p. 548). For the effectiveness of the pre-emption right, in the case when the subject of the pre-emption right refers to real estate or the right to usufruct, it is necessary that the declaration submitted to the obliged party is conducted in the required legal form - namely in the form of a notary deed (see Art. $597 \S 2$ sentence 2 of the Civil Code, as well as the judgment of the SUPREME COURT 2002, IV CKN 784/02).

In principle, the sanction for the violation of the pre-emption right refers to liability in damages (Art. $599 \S 1$ of the Civil Code). This means that an unconditional contract concluded with the violation of the pre-emption right is valid, whereas, the pre-emption right expires, unless it has been entered into the land and mortgage register held for real estate covered by the pre-emption right, and thus, gained so-called extended efficiency. In such a situation, the pre-emption right still exists and the current owner of real estate is the party obliged under the pre-emption right (see Art. 16 item 1 and item 2 point 1, and Art. 17 of the Act of $6^{\text {th }}$ July 1982 on the Land and Mortgage Register, Journal of Laws of 2013 item 707; SUPREME COURT 2001, III CKN 461/00).

However, if the pre-emption right is vested in the State Treasury or unit of self-government, coowner or lessee by the act, an outright sale is invalid (Art. $599 \S 2$ of the Civil Code). The sanction of invalidity is also provided in the statutory pre-emption right regulated by separate provisions. The invalidity of the legal activity means that it does not cause any legal effects, neither between the parties to the activity nor in regards to any third parties, including the entity eligible under the preemption right (BIENIEK, RUDNICKI 2011, p. 571). If the entity eligible were to submit a declaration on the execution of the pre-emption right, in such situation, the declaration will not cause the real estate sales contract between the party obliged and the party eligible to become effective. It is also not able to compensate for such invalid legal activity (SUPREME COURT 2001, III CKN 453/99; SUPREME COURT 2002, V CKN 1374/00).

\section{The back-in right}

The reservation of the back-in right results in the fact that, within the reserved period of time, the seller may, at any moment, effect, through the declaration of will submitted to the buyer, the return sale (GAWILK et al. 2010, p. 172). Thus, the binding of parties with the back-in right demonstrates an obligatory nature. If the purchaser, irrespective of the reservations made, disposed of the item, for instance for the benefit of a third party, and encumbered the item with the effective erga omnes right (thus also against the authorized party), the purchaser would be obliged to perform restitution in order to enable the seller to exercise the seller's rights. In the event that the purchaser fails to do the above, the purchaser may bear responsibility for non-compliance with the obligation (Art. 471 and the following of the Civil Code) (CZACHÓRSKI et al. 2007, p. 451; GAWLIK et al. 2010, p. 173).

The reservation of the back-in right may be effected both in the sale contract itself (as so-called additional contractual reservation) as well as in an additional arrangement (GAWLIK et al. 2010, p. 173) concluded later on by the parties. Such reservation is of ancillary nature, which means, that it may not be established without the effective conclusion of the basic contract, namely the sales contract (BOGUCKI 1995, p. 137; GOLECKI 2003, p. 7). The back-in right is, thus, dependent on the conclusion of a sales contract (GAWLIK et al. 2010, p. 173). 
The doctrine generally accepts the admissibility of the reservation of the back-in right in a real estate sales contract (BIENIEK, RUDNICKI 2011, p. 571; GAWLIK et al. 2010, p. 173). In the light of the principles of the freedom of contract, one may fully accept the fact that the parties will make such a reservation in the contract transferring ownership, or in a contract separate to the sales contract (preceding the main contract or concluded thereafter) (BIENIEK, RUDNICKI 2011, p. 571; GAWLIK et al. 2010, p. 173; BOGUCKI 1995, p. 132; GOLECKI2003, p. 7). On the other hand, rules for establishing backin price stipulated in Art. 594 of the Civil Code, shall be considered as obsolete, infringing the market principle of establishing prices for repurchased items by the seller (ZIEMIANIN, 2008, p. 16) as well as the principle of equal consideration. Cases when the legislator shaped the statutory back-in right are a thing of the past. They were stipulated by Art. 29 item 5 of the Act of 19.10 .1991 on management of real estate belonging to the State Treasury (uniform text, Journal of Laws of 2012 item 1187 as amended) granting the Agricultural Property Agency the back-in right on behalf of the State Treasury for a period of five years, counting from the date of acquisition from the Agency, with the exception of real estate located within the boundaries of special economic zones. The scope of application of this provision applied to all real estate previously sold by the Agency, with the exception of real estate located within the boundaries of special economic zones. This provision was faced with justifiable criticism of the doctrine (ZIEMIANIN, 2008, p. 16) and ultimately became void under the decree of the Constitutional Tribunal of $18^{\text {th }}$ March 2010 (K8/08, Journal of Laws No. 48, item 287) as incompliant with Art. 2, Art. 21 item 1 and Art. 64 in relation to Art. 31 of the Constitution (Journal of Laws No. 78 item 483 as amended).

Currently, the back-in right may operate in real estate trading as the law of contract, in compliance with the principle of contractual freedom, restricted by the legislator in such a manner that, with consideration to the protection of the purchaser's interests, it may not be reserved for a period longer than five years. Longer timeframes, if such had been reserved, are reduced to five years (Art. $593 \S 2$ of the Civil Code). Such a regulation is established in order to secure the endangered interests of the purchaser who, as a result of the reserved back-in right, has limited rights, for instance in terms of conducting investments (GAWLIK et al. 2010, p. 173). After the reserved timeframe has passed, the back-in right expires. The period for the execution of the back-in right is counted from the date the sales contract in which the back-in right has been reserved is concluded, or from when the contract was amended (supplemented) with this additional reservation. It is noteworthy that the parties do not have the possibility to arrange otherwise with regard to the commencement of the period (GAWLIK et al. 2010, p. 173). A longer back-in period reduces the risk of the definite loss of property by the owner but increases the probability of its insolvency. The optimal timeframe for the execution of this right should balance these effects (BAKER, MiCELI, SIRMANS, 2008, pp. 31-45).

If the reservation of the back-in right was included in a real estate sales contract, as its element (accidentalia negotti), it is subjected, on the same basis as the entire contract, to the anticipated form of transferring the real estate, namely in the form of a notary deed (Art. 158 of the Civil Code). If such a reservation was included in a separate arrangement which modifies (supplements or alters) the main contract - the real estate sales contract, then, in compliance with Art. $77 \S 1$ of the Civil Code, the arrangement will also require the form of a notary deed.

The reservation of the back-in right for the seller offers the seller a unilateral-modification clause (GAWLIK et al. 2010, p. 174; JEZIORO et al. 2008, p. 1046). From the moment the declaration on the execution of the back-in right is submitted, an obligation occurs to retransfer the ownership of the item (real estate) to the seller. The execution of the back-in right establishes a commitment which results in the obligation to conclude a contract transferring the ownership title - with material consequences (KATNER 1992, p. 77; BOGUCKI 1995, p. 193; JEZIORO et al. 2008, p. 1048). The above

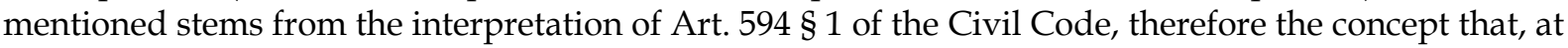
the moment of submitting the declaration on executing the back-in right, the return sale contract is already effected and it is thus not necessary to conclude a separate contract (CZACHÓRSKI et al. 2007, p. $451)$, is not acceptable.

The execution of the back-in right is effected through a declaration submitted to the buyer by the seller. In the case that the conclusion of the sales contract necessitates the observation of the special form required in cases of transferring the ownership title to real estate (Art. 158 of the Civil Code), the declaration of the execution of the back-in right shall be submitted in the same form (Art. $593 \S 2$ of the Civil Code). Based on the above, it is required to submit the declaration of will in the form of a notary 
deed for the execution of the back-in right. If the purchaser refuses, after the execution of the back-in right by the party authorized, the return transfer of ownership, the authorized party may demand the title to the real estate to be transferred before the courts. In such a situation, the final judgment of the court issued under Art. 64 of the Civil Code in relation to Art. 1047 of the Civil Proceeding Code shall replace the declaration of the person who purchased the item burdened with the back-in right, and who has the obligation under the back-in right (JEZIORO et al. 2008, p. 1048; GAWLIK et al. 2010, p. 173).

Analogically to the case of the pre-emption right, "reification" of the back-in right may occur through it being entered into the land and mortgage register for real estate. It will then become effective against every owner of the real estate burdened with that right, unless of course the right expires as a consequence of the passing of the period for which it may be reserved.

\section{The redemption right}

The redemption right is defined as a means of protection for owners against ownership loss and is dependent on many factors, among others political, social, and demographic (BAKER, MICELI, SIRMANS, 2008, pp. 31-45). Polish regulations on the redemption right are not, however, homogenous, which hinders their application. Due to the purpose and character of redemption, as well as the entity which is authorized to exercise such right, we may distinguish redemption rights vested in the State Treasury demonstrating the expropriation character and purpose as well as various claims for redemption, which protect, first of all, the owner and the owner's interests provided for in the Civil Code as well as specific provisions (RUDNICKI 1999, p. 30; BIENIEK, RUDNICKI 2011, p. 572). They stem, for instance, from outlays in land belonging to a third-party, crossing the borderline at the time of construction, and changes in the development plan which make the current use of real estate impossible or considerably hinder it. Irrespective of the above mentioned, there are also provisions which authorize public administration organs to "redeem" land for defined purposes. However, in such cases these organs are not granted sovereign functions (imperium) or claims for redemption, thus, they are not considered as the redemption right or the claim for redemption (RUDNICKI 1999, p. 30).

The legal character of the redemption right is not homogenous. In previous systems, the redemption right with the expropriation character constituted a variant of the statutory pre-emption right. The actual execution of the redemption right was effected through the submission of a declaration of execution in the form of a notary deed. From the moment the seller of the real estate gained knowledge of such declaration, the real estate became state property (RUDNICKI 1999, p. 30; BIENIEK, RUDNICKI 2011, pp. 572-573). Thus, the redemption right constituted a particular mutation of the pre-emption right (DOMIŃCZYK 1996, p. 58). Currently, the right provided for in Art. 59 of the Act on Regional Self-Government ought to be included in redemption characterized by an expropriation nature. It is significant that this provision anticipates that, when a voivodeship (province) or any other provincial legal entity sells objects with a particular scientific, historical, cultural or environmental value, the State Treasury shall be authorized to enjoy the pre-emption or redemption right executed according to the principles specified in the Civil Code. In the light of the cited regulation, a juridical problem occurs with regard to the possibility of applying the relevant provisions of the Civil Code, as the provisions of this Code do not regulate stricte the redemption right, but only grant, in defined situations, the claim for the redemption of a plot of land occupied for construction, or the claim for the transfer of ownership in the plot of land occupied (for construction) against appropriate remuneration (Art. 151 and 231).

Literature correctly points out that Art. 59 of the Act on Self-Government shall be applicable in cases when the subject of the sale refers both to movable property and real estate (RUDNICKI 1999, pp. 34-35; BIENIEK, RUDNICKI 2011, p. 573); moreover, in cases when the voivodeship or any other provincial legal entity sells the item, thus a disposition as a result of which ownership is transferred to the purchaser. Thus, the provision does not restrict the disposal to defined types of legal activities (e.g. sale). Furthermore, it is not important whether the sale was effected against payment or free of charge.

As it has already been mentioned, a problem occurs with regard to referring the redemption right to "rules defined in the Civil Code", as the Civil Code does not provide for such rules. Thus, the redemption right granted to the State Treasury shall be considered as devoid of purpose, as it may not be executed for reasons of a legal nature (RUDNICKI 1999, p. 36). Differently, Bieniek points out that one shall assume that, in the case of a sale, the State Treasury shall have the pre-emption right, and in the case of other legal activities (e.g. exchange, donation) - the redemption right (BIENIEK, RUDNICKI 2011, p. 573). 
On the other hand, provisions of Art. 596-602 of the Civil Code are applicable with regard to the execution of the pre-emption right provided for in Art. 59 of the Act on the Regional Self-Government, however, the pre-emption right will not be restricted, in this case, exclusively to the sales contract, but will apply to all cases of the alienation of an item subject to that right. The legal character of the provisions which grant the claim for redemption does not raise any doubts. The legislator, both in cases defined in the Civil Code (Art. 151, 231) as well as in specific laws (see, among others, Art. 113 item 3 of the Act of 21 ${ }^{\text {st }}$ August 1997 on Real Estate Management, Journal of Laws of 2010 No. 102, item 651 as amended; Art. 36 item 1 of the Act of 27th March 2003 on Spatial Development and Planning, Journal of Laws of 2012 No. 80, item 717 as amended; Art. 129 of the Act of 27th April 2001 Environmental Protection Law, Journal of Laws 2013, item 1231; Art. 18 item 3 of the Act of 9'th June 2011 Geological and Mining Laws Journal of Laws No. 163, item 981 as amended.), grants the defined entity (generally the owner) the claim for redemption. The core aspect of this claim refers to the possibility of demanding certain action to be taken by the defined entity, in the form of transferring the right being the subject of the redemption. The claim with which the obligation is correlated constitutes a form of a subjective right (RUDNICKI 1999, p. 37; ZIEMIANIN, KUNIEWICZ 2007, p. 92). The obligatory execution of the claim is effected pursuant to Art. 64 of the Civil Code in relation to Art. 1047 of the Civil Proceeding Code, which stipulates that the final judgment of the court stating the obligation of a given person to submit the declaration of will replaces such a declaration (see Supreme Court 1967, III CZP 32/66).

\section{Priority of acquisition}

Under Polish law, there is one more institution related to real estate trading in the form of the priority right in real estate acquisition, which is vested in various participants of trading under specific laws. It is important that the institution of priority in acquisition has not been distinguished by grouping together regulations that regulate it into one legal act. The provisions stipulating priority in acquisition were presented in the Act of 29th April 1992 on land management and real estate expropriation (Art. 30) (Journal of Laws No. 14, item 74 as amended), and are currently presented in the Act of $21^{\text {st }}$ August 1997 on Real Estate Management, the Act of 15 th December 2000 on Rules on Selling Apartments being the property of state enterprises, certain commercial companies with State Treasury shareholding, state legal persons, as well as certain apartments being the property of the State Treasury (Journal of Laws of 2001 No 4, item 24 as amended), in the Act of 19th October 1991 on the management of agricultural real estate of the State Treasury (Journal of Laws of 2012, item 1187 as amended) as well as in the Act of 20th December 1996 on Sea Ports and Harbors (Journal of Laws of 2010 No 33, item 179). Furthermore, priority in acquisition may stem not only from an act, but also from the regulation of the voivode [voivodeship governor] referring to real estate constituting the property of the State Treasury, as well as the resolution of a competent council or local government assembly referring to real estate constituting the property of units of territorial self-government (see Art. 34 item 6 of the Act on Real Estate Management).

Priority in acquisition constitutes an exception to the principle of contractual freedom (Art. $353^{1}$ of the Civil Code), restricting the autonomy of the parties' intentions as well as the freedom to exchange goods in a market economy. Priority in acquisition clashes with the seller's competence to decide with whom to conclude the contract. The trading partner is somewhat imposed on the seller, as this partner is selected in a special manner, with consideration of preferences stipulated for a defined category of entities (ŚWIDERSKI 2000, p. 84). The institution of priority does not apply to all forms of real estate trading. In principle, it applies to trading in real estate that is the property of the Treasury and selfgovernments. It also applies to cases of selling ownership in real estate, handing over land property for perpetual usufruct as well as establishing a separate ownership in premises (ŚWIDERSKI 2000, p. 90, p. 94).

The group of entities enjoying the right of priority in acquisition demonstrates a rather homogenous character. All the former owners of sold real estate, their heirs, tenants and lessees of housing facilities, as well as persons occupying company premises enjoy priority in acquisition. The justification for granting these entities the right of priority in acquisition stems from principles of righteousness and social justice, which constitute a certain compromise in the consequence of social and ownership transformations (ŚWIDERSKI 2000, pp. 91-92).

The legal character of priority has not been settled according to norms. According to the Supreme 
Court, priority refers to the statutorily defined preference of candidates with regard to the purchase of given real estate. It refers to "the elimination of other entities applying for the same item". Its juridical construction is not based on the unilateral-modification clause, but on the ban to dispose of the item in a manner violating the pre-emption right, immanently related to such right. The execution of the priority is possible only when the addressee of the ban establishes with his or her conduct a situation in which the ban becomes valid (SUPREME COURT 1992, III CZP 62/92), namely, if the real estate has been planned to be put up for sale by a competent organ (judgment of the Administrative Court in Katowice of 13.11.2012, I ACa 539/12).

The provisions which refer to the priority right do not provide for a claim for concluding a contract of ownership transfer. This right is not a subjective right from which the claim "forcing" the owner to sell the real estate would result. According to the current legal status, the priority right does not constitute the source of the claim to conclude a contract transferring ownership in real estate. Thus, there is no basis to construe any claim for the conclusion of the contract transferring ownership. This opinion is well established in jurisprudence (CONSTITUTIONAL COURT 2003, K 24/01; CONSTITUTIONAL COURT 1996, W 19/95; SUPREME COURT 1992, III CZP 62/92; SUPREME COURT 2000, V CKN 180/00). The consequences of violating the priority right are not always statutorily defined or differ. For instance, Art. 3 item 1 of the cited Act of $15^{\text {th }}$ September 2000 sanctions the alienation of a company apartment with violation of the priority right, effecting invalidity of such legal activity. On the other hand, Art. 36 of the Act on Real Estate Management stipulates that in the event that priority in acquisition, referred to in Art. 34 items 1-5 of the Act on Real Estate Management, is infringed, the State Treasury and the unit of territorial self-government "bear responsibility according to general rules", which means that these entities are subject to liability in damages under Art. 417 of the Civil Code (BIENIEK, RUDNICKI 2011, p. 576). The lack of homogenous solutions and, at the same time, the assessment of the results of violating the priority right, will be possible only after establishing exactly what case of priority we are dealing with (ŚWIDERSKI 2000, p.109).

\section{Final conclusions}

An act may be the source of all the analyzed institutions (with the current exception of the back-in right). In the case of the pre-emption and back-in right, their source may additionally refer to the legal action of the parties to the transaction interested in their establishment. In such a case, within the scope of the contractual freedom, the parties decide on certain limitations in the disposing of real estate.

With the use of the discussed legal instruments, the legislator executes various goals related to real estate management. Those goals are, by principle, of a thetic nature; they allow a defined ownership structure to be shaped, as well as the rational management of real estate of a given location, character and allocation in the space management plan, or which had been previously purchased from particular entities. It is important that the discussed instruments may also have a strong axiological justification, related to the ownership changes which took place in the nineties of the twentieth century, focusing on the execution of the principle of social justice. The conducted legal and comparative analysis confirms the posed thesis that the examined institutions constitute factors limiting trading in real estate, which simultaneously secures the interests of given entities.

A common feature of all the analyzed instruments, irrespective of their source of origin, refers to the fact that they restrict the autonomy of the parties and freedom to exchange goods in a market economy. Their execution, in certain aspects, questions the competence of the seller to decide with whom to conclude the contract transferring ownership in real estate. Some of them (the pre-emption right, the acquisition right) require that the seller who intends to sell the real estate shall observe a certain procedure, the violation of which may result in liability in damages, and sometimes even in the invalidity of the concluded contract. In a certain sense, the examined institutions limit the ownership right in the context of the ability to freely dispose of the item (Art. 140 of the Civil Code).

Specifying the legal character of the examined institutions, the manner in which the rights are executed, the results of the infringements of obligations stipulated in the act (contract), or finally, the potential means of enforcing the right guaranteed by the act (contract) are of considerable meaning to their application in practice. The conducted analysis confirms the thesis that the legal character of the examined rights is not homogenous. The legislator gives pre-emption and back-in rights the form of a regulating power; the redemption right takes, as a matter of principle, the form of a claim, the execution of which may occur by way of agreement or court proceedings. It is important that the 
execution of the claim takes place irrespective of the fact whether the current owner of the real estate expresses the intention to sell it. Priority in acquisition is the "weakest" from the juridical perspective, as its construction does not provide for the obligation to alienate real estate for the party authorized, the correlate of which would refer to a relevant claim. Priority in acquisition grants the possibility to acquire real estate before other entities only in the situation when the owner has put it up for sale (ŚWIDERSKI 2000, p. 111).

It is significant that the legislator does not limit the application of the given instrument only to a specified type of real estate ownership (among others, State Treasury, territorial self-governmental unit), but often, having in consideration the interests of weaker entities (among others, tenants and lessees), guarantees them the possibility to acquire real estate with priority over other potential purchasers.

Additionally, the manner in which the power guaranteed by the act (contract) is executed is also not homogenous. In the case of the pre-emption right, it is necessary to divide the contracting process into two stages: the contract obliging ownership to be transferred as well as the contract with the material effect. It is obvious that such a manner extends the time necessary to conclude the contract with the material effect, as the legislator provides for, in principle, a one-month period for the preemption right to be executed by the authorized entity. The manner in which the right is executed is effected by the submission of the determined intent of will (in the form of a notary deed) - in the case of the pre-emption and back-in rights, and in case of redemption right - by concluding a contract, or obtaining a decree imposing the submission of the intent of will, or finally by submitting the declaration of acquisition within the timeframe defined by the act - with regard to priority in acquisition. Moreover, the results of the failure to fulfill obligations defined in the act or contract are not homogenous. Where the pre-emption right is concerned, a sale conducted unconditionally may be invalid, or bring about compensation liability. A similar solution is provided for by the legislator in the case of infringing the right of priority in acquisition. In the case of back-in and redemption, the execution of the claim is exerted in the form of a court proceeding, applying the construction of a substitute declaration of will. Basically, for each of the discussed institutions the legislator provides for the possibility of applying national means of enforcement, although they may be stronger (ownership transfer) or weaker (compensation).

The tendency of the legislator should refer to the restriction of the discussed instruments of statutory character to an absolute minimum. First of all, the types of real estate covered by the preemption, back-in, redemption or priority in acquisition right should be precisely defined. Application in practice so far has revealed that the provisions indicating the types of real estate covered by a given power are not always precise and that their application in practice causes problems. In the course of works over the new Civil Code, the positioning of the basic framework of provisions regulating the analyzed institutions should be considered. They ought to be placed in a single group within the scope of the detailed part of liabilities. The current division of the regulations into numerous legal acts, including the application of references to regulations which are impossible to apply (See Art. 59 of the Act of Regional Self-government), constitutes a considerable impediment for their application in practice. It is necessary to modernize regulations on the back-in right, from the perspective of price determination by Art. 594 of the Civil Code, which infringe the market principle of price determination as well as the principle of the equivalence of services. One ought to consider to what legal events the said institutions shall refer to. The conducted analysis reveals that, in their current shape, they refer, in principle, to the sales contract; however, in certain cases, detailed regulations expand the scope of their application to other cases of alienation (Art. 59 of the Act of Regional Selfgovernment), which may additionally include legal activities other than sales leading to the transfer of ownership (exchange, donation, handing over of real estate). Moreover, they include cases of transferring perpetual usufruct or establishing separate ownership of premises. Regulations introducing restrictions with regard to disposing of real estate ought to be formulated precisely so that there are no problems with their application, whereas their interpretation in the process of applying the law should be restrictive. On the basis of the purpose they are intended to serve, one may not conclude that they cover situations that are not mentioned within them. It is necessary to eliminate institutions from the legal system, such as the redemption right referred to in Art. 59 of the Act on Territorial Self-government, if their legal constitution is defective and practically impossible to be applied in practice. One should consider the statutory harmonization of the results of the execution of 
the pre-emptive and back-in rights, as the existing separate legal solutions do not seem justified considering the uniform legal character of the discussed institutions.

\section{References}

BAKer M.J., Miceli T.J., SIRMANS F.C., Economic Theory of Mortgage Redemption Laws, Real Estate Economics, 2008, Vol. 36, Issue 1, pp. 31-45.

BIENIEK G. [IN:] BIENIEK G., RUDNICKI S., Nieruchomości. Problematyka prawna (Real Estate. Legal Aspects), Warszawa 2011, pp. 540 and the following.

BoguCKI S., Prawo odkupu (The Back-in Right), Rejent 1995, No. 9, pp. 132, 137, 193.

CZACHÓRSKI W. [in:] CZACHÓRSKI W., BRZOZOWSKI A., SAFJAN M., SOWROŃSKA-BOCIAN E., Zobowiazania. Zarys wyktadu (Liabilities. The Outline of the Lecture), Warszawa 2007, p. 451.

CZARNECKI R., Prawo pierwokupu wedlug ustawy o gospodarce terenami w miastach $i$ osiedlach, (The Preemption Right Under the Municipal Areas and Estates Management Act), NP. 1963, Journal 11, p. 1193 and the following.

DOMIŃCZYK T., Pierwokup na tle przepisów ustawy o gospodarce gruntami i wywłaszczaniu nieruchomości (Pre-emption in the Light of the Provisions of the Land Management and Real Estate Expropriation Act), Rejent 1996 , No. 1, p. 57 and the following.

GAWLIK Z. [in:] KidyBA A. (ed.), Kodeks cywilny. Komentarz. Tom trzeci. Zobowiazania. Cześśc szczegótowa (The Civil Code. Commentary. Volume III, Liabilities - a specific part), Warszawa 2010, pp. 173, 174, 178, $179,185$.

GóRECKI J., Umowne prawo pierwokupu (The Contractual Pre-emption Right), Kraków 2000, p. 76.

GOLECKI M. J., Jurydyczna konstrukcja prawa odkupu (Juridical Construction of the Back-in Right), NPN 2003, No. 4, p. 7.

JezIORO J. [in:] GNIEWEK E. (ed.), Kodeks cywilny. Komentarz (The Civil Code. Commentary), Warszawa 2008, pp. 1046, 1048.

KUNICKI A., Zakres skuteczności ustawowego prawa pierwokupu (The Scope of the Effectiveness of the Statutory Pre-emption Right), NP. 1966, No. 12, p. 1529.

LARENZ K., Lehrbuch des Schuldrecht, v. II, München-Berlin 1959, p. 89, 159.

LIESER K., GROH A.P., The Determinants of International Commercial, Real Estate Investment, The Journal of Real Estate Finance and Economics, 2014, Vol. 48, Issue 4 , pp. 611-659.

Miceli T.J., SiRMANS F.C., Time-Limited Property Rights and Investment Incentives, The Journal of Real Estate Finance and Economics, 2005, Vol. 31, Issue 4 , pp. 405-412.

PIET M., EichHOlZ A., Gugler N., KOK N., Transparency, Integration, and the Cost of International Real Estate Investments, The Journal of Real Estate Finance and Economics, 2011, Vol. 43, Issue 1-2, pp. 152-173.

PYZIAK-SZAFNICKA M. [in:] System prawa prywatnego (The Private Law System), Vol. I (ed.) M. Safjan, Warszawa 2007, pp. 709-712.

RADZEWICZ A., WIŚNIEWSKI R., Zmienne, cechy i atrybuty nieruchomości, Studia i Materiały Towarzystwa Naukowego Nieruchomości (Variables, Features and Real Estate Attributes), Studies and Materials of the Real Estate Scientific Association 2012, Vol. 20, No. 1, p. 7.

SCHURING K., Das Vorkaufsrecht im Privatrecht: Geschichte, Dogmatik, ausgewählte Fragen, Berlin 1975, pp. 306-307.

SZPUnAR A., Forma umowy o przeniesienie własności nieruchomości (The Form of the Contract on Real Estate Ownership Transferring) [in:] Księga pamiątkowa dla uczczenia pracy naukowej Kazimierza Przybyłowskiego (A Memorial Book to Commemorate the Scientific Work of Kazimierz Przybyłowski), Warszawa-Kraków 1964, p. 373.

SWACZYNA B., Wptyw uchylenia albo zmiany przepisów na zastrzeżone przez te przepisy prawo pierwokupu (The Influence of Dismissing or Amending Regulations on the Pre-emption Right Reserved by those Regulations), Rejent 2000, No. 10, pp. 74, 80, 81.

TruszKIEWicZ Z., Prawo pierwokupu w świetle ustawy o gospodarce nieruchomościami (The Pre-Emption Right in the Light of the Land Management Act), Rejent 1998 , No. 12, pp. 196, 198, 199.

ZIEMIANIN B., Prawo odkupu nieruchomości rolnej: rozbój w biały dzień (Agricultural Property Back-In Right: Robbery in Broad Daylight), Rzecz. 2008/1/16.

Ziemianin B., KuniewiCZ Z., Prawo cywilne. Cześć ogólna (The Civil Law. General Part), 2007, p. 53.

ŻUŁAWSKA CZ. [in:] Komentarz do Kodeksu cywilego. Księga trzecia (in: Commentary to the Civil Code. Book three. Liabilities), Vol. III, Warszawa 1999, p. 107. 